\title{
Physico-Chemical Parameters of Industrial Effluents from a Brewery Industry in Imo State, Nigeria
}

\author{
Iwuozor Kingsley Ogemdi*, Emuobosa Ejiroghene Gold
}

Department of Pure and Industrial Chemistry, Nnamdi Azikiwe University, Awka, P.O. Box 5025, Nigeria

* Corresponding author E-mail address: Kingsleyiwuozor5@gmail.com, Tel.: +2347034810425

Received: 5 October 2018, Revised: 29 October 2018, Accepted: 17 November 2018

\begin{abstract}
A B S T R A C T
This work examined some physicochemical parameters of effluents from a Brewery Industry in Imo state, Nigeria. This company discharged effluents in non-compliance with the Nigerian National Regulations as confirmed from the Biochemical Oxygen Demand (BOD), Chemical Oxygen Demand (COD), Electrical Conductivity (EC), Nitrogen, and Turbidity results. The heavy metals have concentrations that were within WHO/FEPA limits. The confirmed results posed health risks to several rural communities which rely on the receiving water bodies as their primary source of domestic water. It is necessary for the intervention of appropriate regulatory agencies to ensure the production of high quality treated final effluents. This scenario is typical of most industries in the developing nations where enforcement of environmental regulations is deficient. To avoid pollution, regulatory authorities should closely monitor compliance by industries.
\end{abstract}

Keywords: Effluent, Physicochemical, Heavy metals, Biochemical oxygen demand (BOD), Chemical oxygen demand (COD).

G R A P H I C A L A B S T R A C T

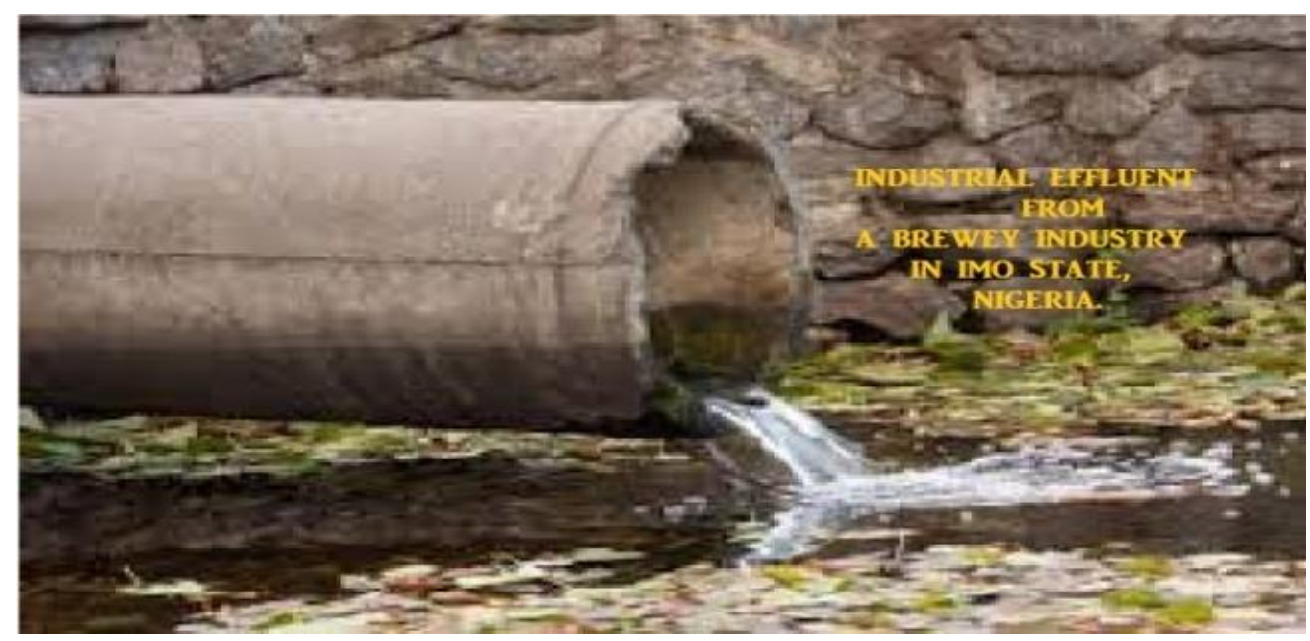




\section{Introduction}

Rivers, lakes and other water bodies serve as a cheap source of effluent disposal by most industries especially in the developing nations [1]. Unarguably, these effluents which are mainly composed of waste water from washing and cooling processes, fluids from machine leakages, reagents and various chemicals, frictionally generated metal particles, scraps, bacteria, grease, heat, dust, minerals and organic matter, especially, when they find their way into rivers. In this sense, they pose serious threats to the aquatic life, plants, animals and human beings that are at the peak of the food chain. Heavy metals like lead are very poisonous; compounds like nitrates when in high concentration are very toxic especially to babies [2, 3].

There is therefore a serious need to carry out a research to find out the elements and compounds present in the effluents of Brewery Industries. The results of the analysis of these effluents will reveal the presence and concentrations of these pollutants. The contents and their concentrations will be compared with a reference standard and if found to be unsafe, recommendations will be made on the proper way of disposing the effluent such that it will not be harmful to life [4].

The term effluent can be defined as liquid waste flowing out of a factory, farm, commercial establishment, or a household into a water body such as a river, lake, or lagoon. In various under-developed countries, untreated sewage and industrial effluents are utilized for the cultivation of crops and vegetables. It is a common practice in Nigeria where farmers suppose it to be a source of irrigation and nutrients for cultivation while administrators assume it as a low cost method of disposal [4,5].

Environmental pollution is one of the chief causes of sickness in our society. Industrial effluents unfortunately have their final destinations in streams, which serve as the main source of water supply to most rural communities. There is need to monitor the effluents discharged by industries to ensure that they comply with regulatory standards.

Effluents are classified by their origin as;
a. Domestic or municipal sewage
b. Atmospheric (rain) run-off
c. Industrial effluent

Municipal Sewage: This consists of water containing food wastes, various washing and laundry wastes, water from lavatories and bath, etc. The waste water is an unstable polydispersed system. The particles can be coarse and very fine and the composition of municipal sewage is relatively constant. All the pollutants are mostly organic of vegetable and animal origin. Inorganic 
impurities are sand, clay, mineral salt, etc. the effluents are dangerous with respect to epidemic diseases of animals and man because, in addition to saprophytic, they contain the most pathogenic organisms infesting man [5].

Run-Off: These are due to atmospheric precipitation i.e., due to rains, snow, street washing, etc. Atmospheric precipitation is polluted with organic and mineral substances contained in the air and on the surface of various ground objects [5].

Industrial Effluent: This originates from industrial enterprises where water is used for various processes and also for washing and rinsing of various machines and equipment [5].

Every industry produces its own characteristic process wastes, as a result of many operations such as washing operations, washing of raw materials, formation of intermediate and final products, etc. [6]. The waste water from washing usually contains small quantity of the process material which impacts the characteristic to the process water. These process wastes are generally of three types:

Inorganic Process Wastes: The effluents from chemical manufacturing industries, etc. contain inorganic process wastes. The inorganic waste does not pose much biological problems other than toxicity when combined with organic waste. They can create problems of the disposal of the organic wastes.

Organic Process Waste: These are waste water from food processing industries, dairies, breweries, textile mills and organic chemicals manufacturing industries. The major pollution problem from industrial waste lies in the disposal of the organic process wastes.

Chemical Wastes: Plants manufacturing acids, bases, detergents, explosives, dyes, insecticides, fertilizers and large number of other substances which are also used as raw materials for further manufacturing process contain chemical wastes. Chemical processes vary widely according to the manufacturing methods which are responsible for these chemical wastes including sedimentation, flocculation, washing, filtering, evaporation, distillation, electrolysis, absorption, crystallization, etc.

Chemical wastes are usually characterized by acidic and basic materials, matter of high Biological Oxygen Demand, color and flammability, but low in suspended solid. Some chemical wastes require biological oxidation treatment methods such as trickling filters and activated sludge. For example, corn starch waste, mixed with domestic sewage can be treated by activated sludge or trickling filter method. Effluents 
when discharged immediately into the environment causes pollution of land or water. Therefore, it is necessary to treat effluent before discharging it into the environment $[7,8]$.

The aim of this study is to analyze the physicochemical compounds and metal concentrations in the effluents generated by a Brewery Industry in Imo state, Nigeria. The results from the analyses will be compared with reference standards to ascertain its compliance with regulatory standards.

\section{Experimental}

\subsection{Collection of Sample}

The effluent samples were collected from the points of discharge of the company. 250 $\mathrm{mL}$ glass bottles were used to collect samples for COD and BOD while samples for the physicochemical parameters were collected with plastic bottles pre-cleaned by washing with non-ionic detergents and rinsed with tap water.

\subsection{Experimental}

All field meters and equipment were checked and calibrated according to the manufacturer's specification. $\mathrm{pH}$, temperature, transparency and depth were determined while on site. Other parameters including heavy metals were analyzed in the laboratory. pH was measured using Hanna model HI991300 pH meter, Heavy metal analysis was conducted using Varian AA 240
Atomic Absorption Spectrophotometer, Electrical Conductivity was measured using Lab Conductivity Meter Tester Model DDS307, Total Dissolved Solids were measured using TDS meter test set 139 and nitrate was determined using a PD303 UV spectrophotometer.

\subsection{General Procedure}

\subsubsection{Determination of $\mathrm{pH}$}

Method: pH was measured by electrometric method using laboratory $\mathrm{pH}$ meter Hanna model HI991300.

\section{Procedure}

i) The electrodes were rinsed with distilled water and blot dry.

ii) The $\mathrm{pH}$ electrodes were then rinsed a small beaker with a portion of the sample.

iii) Sufficient amount the sample was poured into a small beaker to allow the tips of the electrodes to be immersed to a depth of about $2 \mathrm{~cm}$. The electrode was at least 1 $\mathrm{cm}$ away from the sides and bottom of the beaker.

iv) The temperature adjustment dial was set accordingly.

v) The $\mathrm{pH}$ meter was turned on and the $\mathrm{pH}$ of the sample recorded.

\subsubsection{Determination of Electrical Conductivity}

Analysis was carried out according to American Public Health Association 2510 B guideline Model DDS-307. 


\section{Procedure}

i) The conductivity cell was rinsed with at least three portions of the sample.

ii) The temperature of the sample was then adjusted to $20 \pm 0.1^{\circ} \mathrm{C}$.

iii) The conductivity cell containing the electrodes was immersed in sufficient volume of the sample

iv) The conductivity meter was turned on and the conductivity of the sample was recorded.

\subsubsection{Determination of Total Dissolved Solids (Tds)}

Method: The total dissolved solids was determined using APHA 2510 A TDS 139 tester [9].

The fiber filter disc was prepared by placing it, wrinkled side up in the filtration apparatus. Vacuum was applied and the disc was washed with three successive $20 \mathrm{~mL}$ washings of distilled water. A clean evaporating dish was heated to $180 \pm 2{ }^{\circ} \mathrm{C}$ in an oven for one hour, cooled and stored in a desiccator until needed. It was weighed immediately before use. A sample volume was chosen to yield between $2.5-200 \mathrm{mg}$ dried residue. $50 \mathrm{~mL}$ of the well-mixed sample was filtered through the glass-fiber filter and it was washed with three successive $10 \mathrm{~mL}$ volumes of distilled water, allowing complete draining between washings. Suction was continually applied for about three minutes after filtration was complete.

Filtrate was transferred to a weighed evaporating dish and evaporated to dryness on a steam bath. The evaporating dish was finally dried for at least one hour in an oven at $180 \pm 2{ }^{\circ} \mathrm{C}$, cooled in a desiccator to and was weighed.

Calculation:

$$
\text { TDS }=\frac{(A-B) * 10^{3}(\mathrm{mg} / \mathrm{L})}{\text { Sample Volume }(\mathrm{mL})}
$$

Where A = weight of dish + solids (mg)

$\mathrm{B}=$ Weight of dish before use (mg)

\subsubsection{Determination of Water Hardness}

Method: Hardness was measured using standard analytical method of APHA [9].

\section{Procedure}

$50 \mathrm{~cm}^{3}$ of the water sample was introduced into a beaker and $1 \mathrm{~cm}^{3}$ buffer solution of $\mathrm{NH}_{3}$ added. Three drops of solocrome Black $\mathrm{T}$ indicator was also added and the solution swirled properly. The mixture was titrated with 0.01 EDTA solution until it changed from wine red to pure blue with no bluish tinge remaining. The total hardness of the water sample was calculated.

Total hardness $\left(\mathrm{mg} / \mathrm{CaCO}_{3}\right)$

$$
=\frac{\text { Volume of titrant } * 100}{\text { Volume of sample }\left(\mathrm{cm}^{3}\right)}
$$

\subsubsection{Determination of Nitrate}

Method: Nitrate was determined using a 
PD303 UV spectrophotometer [9].

\section{Procedure}

A known volume (50 $\mathrm{mL})$ of the sample was pipetted into a porcelain dish and evaporated to dryness on a hot water bath. 2 $\mathrm{mL}$ of phenol disulphonic acid was added to dissolve the residue by constant stirring with a glass rod. Concentrated solution of sodium hydroxide and distilled water was added with stirring to make it alkaline.

This was filtered into a nessler's tube and was made up to $50 \mathrm{~mL}$ with distilled water. The absorbance was read at $410 \mathrm{~nm}$ using a spectrophotometer after the development of color. The standard graph was plotted by taking concentration along $\mathrm{X}$-axis and the spectrophotometric readings (absorbance) along Y-axis. The value of nitrate was found by comparing absorbance of sample with the standard curve and expressed in mg/L.

\section{Method of Calibration}

Standard nitrate solution was prepared by collecting $50 \mathrm{~mL}$ of the stock solution, $2 \mathrm{~mL}$ of phenol disulphonic acid added and diluted to $500 \mathrm{~mL}$, to give $1 \mathrm{~mL} 10 \mu \mathrm{g}$. The solution of various strengths ranging from 0.0 (blank) to $1.0 \mathrm{mg} / \mathrm{L}$ at the intervals of 0.2 $\mathrm{mg} / \mathrm{L}$ was prepared by diluting stock solution with distilled water (Table 1).

\subsubsection{Determination of Phosphate}

Method: Phosphate was measured using 4500-P B.5 and 4500-PE [9].

\section{Procedure}

$100 \mathrm{~mL}$ of the homogenized and filtered sample was pipetted into a conical flask. The same volume of distilled water (serving as control) was also pipetted into another conical flask. $1 \mathrm{~mL}$ of $18 \mathrm{M} \mathrm{H}_{2} \mathrm{SO}_{4}$ and $0.89 \mathrm{~g}$ of ammonium persulphate were added to both conical flasks and gently boiled for $11 / 2$ hours, keeping the volume of $25-50 \mathrm{~cm}^{3}$ with distilled water. It was then cooled, one drop of phenolphthalein indicator was added and after being neutralized to a faint pink color with $2 \mathrm{M} \mathrm{NaOH}$. The pink color was discharged by drop wise addition of $2 \mathrm{M} \mathrm{HCl}$, and the solution was made up to $100 \mathrm{~mL}$ with distilled water. For the calorimetric analysis, $20 \mathrm{~mL}$ of the sample was pipetted into test tubes, $10 \mathrm{~mL}$ of the combined reagent added, shaken and left to stand for 10 minutes before reading the absorbance at $690 \mathrm{~nm}$ in a spectrophotometer, using $20 \mathrm{~m}$ of distilled water plus $1 \mathrm{~mL}$ of reagent as reference.

\section{Method of Calibration}

Standard phosphate solution: $219.5 \mathrm{mg}$ of dried AR potassium hydrogen phosphate was dissolved in distilled water and made up to $1000 \mathrm{~mL}, 1 \mathrm{~mL}=50.0 \mu \mathrm{g}$ of phosphate. 10 $\mathrm{mL}$ of the stock solution was made up to $1000 \mathrm{~mL}$ to give $1 \mathrm{~mL}=0.05 \mathrm{mg}$. standards of strength ranging from 0 to $0.05 \mathrm{mg} / \mathrm{L}$ at intervals of $0.01 \mathrm{mg}$ is prepared by diluting the stock with distilled water (Table 2). 
Table 1. Preparation of standard calibration curve for nitrate determination

\begin{tabular}{cccc}
\hline Standard Solution(mL) & Distilled Water $(\mathbf{m L})$ & Concentration $\mathbf{( m g} / \mathbf{L})$ & Absorbance \\
\hline 0.00 & 1.00 & 0.00 & 0.00 \\
0.20 & 0.80 & 0.002 & 0.004 \\
0.40 & 0.60 & 0.004 & 0.012 \\
0.60 & 0.40 & 0.006 & 0.017 \\
0.80 & 0.20 & 0.008 & 0.020 \\
1.00 & 0.00 & 0.010 & 0.026 \\
\hline
\end{tabular}

Table 2. Preparation of standard calibration curve for phoshate determination

\begin{tabular}{cccc}
\hline Standard Solution(mL) & Distilled Water $(\mathbf{m L})$ & Concentration $(\mathbf{m g} / \mathbf{L})$ & Absorbance \\
\hline 0.00 & 1.00 & 0.00 & 0.00 \\
0.20 & 0.80 & 0.001 & 0.032 \\
0.40 & 0.60 & 0.002 & 0.048 \\
0.60 & 0.40 & 0.003 & 0.066 \\
0.80 & 0.20 & 0.004 & 0.075 \\
1.00 & 0.00 & 0.05 & 0.088 \\
\hline
\end{tabular}

\subsubsection{Determination of Chloride}

Method: Chloride was analyzed according to EPHA standard method.

\section{Procedure}

A $100 \mathrm{~mL}$ of the clear sample was pipetted into an Erlenmeyer flask and the $\mathrm{pH}$ was adjusted to 7-10 with either $\mathrm{H}_{2} \mathrm{SO}_{4}$ or $\mathrm{NaOH}$ solution. Then, $100 \mathrm{~mL}$ of $\mathrm{K}_{2} \mathrm{CrO}_{4}$ indicator solution was added with standard solution of $\mathrm{AgNO}_{3}$ in a permanent reddish brown coloration. The $\mathrm{AgNO}_{3}$ titrant was standardized and a reagent blank established. A blank of $0.2-0.3 \mathrm{~mL}$ was usually used.

Calculation;

Chloride concentration $=$ Titre value $(\mathrm{x}) \times 10$ $=10 \times \mathrm{mg} / \mathrm{L}$.

\subsubsection{Determination of Sulphate}

Method: sulphate was analyzed according to APHA standard method.

\section{Procedure}

$250 \mathrm{~cm}^{3}$ of the water sample was evaporated to dryness on a dish. The residue was moistened with a few drops of concentrated $\mathrm{HCl}$ and $30 \mathrm{~cm}^{3}$ distilled water was added. This was boiled and then filtered. The dish was rinsed and the filter paper was washed with several portions of distilled water and both filtrate and washings were added together. This was heated to boiling and then $10 \mathrm{~cm}^{3}$ of $10 \% \mathrm{BaCl}_{2}$ solution was added, drop by drop with constant steering. The mixture was digested for about 30 minutes, filtered and the filter paper was washed with warm distilled water. It was then ignited, cooled and weighed in an already weighed crucible. 
Calculation

$\mathrm{Mg} / \mathrm{dm}^{3} \mathrm{SO}_{4}^{2-}=\mathrm{mg} \mathrm{BaSO}_{4} \times 411.5 \mathrm{~cm}^{3}$ of water sample.

\subsubsection{Analysis of Heavy Metals}

Heavy metal analysis was conducted using Varian AA240 atomic absorption spectrophotometer according to the method of American Public Health Association.

\section{Principle}

Atomic absorption spectrometer's working principle is based on the sample being aspirated into the flame and atomized when the AAS's light beam is directed through the flame into the monochromator, and onto the detector that measures the amount of light absorbed by the atomized element in the flame. Since metals have their own characteristic absorption wavelength, a source lamp composed of that element is used, making the method relatively free from spectral or radiation interferences. The amount of energy of the characteristic wavelength absorbed in the flame is proportional to the concentration of the element in the sample.

\section{Procedure}

The sample was thoroughly mixed by shaking, and $100 \mathrm{~mL}$ of it is transferred into a glass beaker of $250 \mathrm{~mL}$ volume, to which 5 $\mathrm{mL}$ of concentrated nitric acid is added and heated to boil till the volume was reduced to about 15-20 mL, by adding conc. nitric acid in increments of $5 \mathrm{~mL}$ till all the residue is completely dissolved. The mixture was cooled, transferred and made up to $100 \mathrm{~mL}$ using metal free distilled water. The sample was aspirated into the oxidizing airacetylene flame. When the aqueous sample was aspirated, the sensitivity for $1 \%$ absorption was observed. (Table 3 shows the instrumental parameters).

Table 3. Instrument (AAS) settings

\begin{tabular}{cccc}
\hline Metal & Wavelength(nm) & Flame type & Uptake time(sec) \\
\hline Lead & 217.0 & Air/acetylene & 5 \\
Iron & 248.3 & Air/acetylene & 5 \\
Zinc & 213.9 & Air/acetylene & 5 \\
Copper & 324.7 & Air/acetylene & 5 \\
Silver & 302.5 & Air/acetylene & 5 \\
Arsenic & 193.7 & N 2 O/acetylene & 5 \\
Magnesium & 285.2 & Air/acetylene & 5 \\
Calcium & 422.7 & N2O/acetylene & 5 \\
Sodium & 589.0 & Air/acetylene & 5 \\
Potassium & 766.5 & Air/acetylene & 5 \\
Iron & 248.3 & Air/acetylene & 5 \\
\hline
\end{tabular}




\section{Results}

The results of the analysis of the physicochemical Parameters are summarized in Table 4 and Table 5. The
Federal Environmental Protection Agency's limitation guidelines for effluents [10] to be discharged by the Industry is summarized in Table 6.

Table 4. Physicochemical results of sample

\begin{tabular}{cc}
\hline Parameter & Brewery Industry \\
\hline Conductivity $(\mu \mathrm{s} / \mathrm{cm})$ & 10460 \\
pH & 2.25 \\
Turbidity (NTU) & 847 \\
TDS (ppm) & 485 \\
Hardness (ppm) & 2000 \\
Nitrate (mg/L) & 0.320 \\
Phosphate (mg/L) & 0.260 \\
Chloride (mg/L) & 3.5 \\
Sulphate (mg/L) & 80 \\
BOD (mg/L) & 485 \\
COD (mg/L) & 172 \\
\hline
\end{tabular}

Table 5. Elemental analysis results of effluent samples

\begin{tabular}{cc}
\hline Metal & Brewery Industry(ppm) \\
\hline Cadmium & 0.144 \\
Cobalt & 0.020 \\
Lead & 0.10 \\
Copper & 0.036 \\
Chromium & 0.00 \\
Iron & 0.00 \\
Magnesium & 0.9147 \\
Nickel & 0.00 \\
Manganese & 0.051 \\
Zinc & 0.07344 \\
\hline
\end{tabular}

\section{Discussion}

The result of the physicochemical analysis of the industrial effluents (Table 4) showed a wide variation in comparison to the approved standard set by the Federal Environmental Protection Agency [10]. Conductivity of water is used as a measure of the total concentration of ionic species or salt content. Though there is no FEPA guideline for conductivity value, the South
African guideline for conductivity in effluent that will be discharged into river is $250 \mu \mathrm{S}$ $\mathrm{m}^{-1}$. The effluent conductivity value of the company was above this acceptable limit. High conductivity values of effluents can increase the salinity of the receiving river, which may result in adverse ecological effects on the aquatic biota. Such high salt concentrations hold potential health 
hazards $[11,12]$. The $\mathrm{pH}$ value of the Brewery industry (2.25) was exceedingly low when compared with FEPA approved limit of 6-9. Since $\mathrm{pH}$ is a function of hydrogen ion concentration (i.e., $\mathrm{pH}=-\log \left[\mathrm{H}^{+}\right]$), the high acidity of the effluents was probably due to high concentration of hydrogen ion $\left[\mathrm{H}^{+}\right]$ in the effluents. When effluents with low $\mathrm{pH}$ have their ways into water bodies, it causes growth inhibition of bacteria species in the receiving water body [13, 14].

Table 6. Effluent limitation guidelines in Nigeria for all categories of industries units in milligram per litre $(\mathrm{mg} / \mathrm{L})$

\begin{tabular}{|c|c|}
\hline Parameters & Limit for discharge \\
\hline Temperature & $<40^{\circ} \mathrm{C}$ \\
\hline $\mathrm{PH}$ & $6-9$ \\
\hline BOD at $20^{\circ} \mathrm{C}$ & 50 \\
\hline Total suspended solids & 30 \\
\hline Total dissolved solids & 2,000 \\
\hline Chloride (as $\mathrm{Cl}$ ) & 600 \\
\hline Sulphate $\left(\right.$ as $\mathrm{SO}_{2}$ ) & 1000 \\
\hline Sulphide (as $\mathrm{S}^{2}$ ) & 0.2 \\
\hline Cyanide (as CN-) & 0.1 \\
\hline Oil and grease & 20 \\
\hline Nitrate (as $\mathrm{N}^{3-}$ ) & 10 \\
\hline Phosphate (as $\mathrm{P}_{4}^{3-}$ ) & 10 \\
\hline Arsenic (as As) & 0.1 \\
\hline Barium (as $\mathrm{Ba}$ ) & 5 \\
\hline Tin (as Sn) & 10 \\
\hline Iron (as Fe) & 20 \\
\hline Manganese (as Mn) & 5 \\
\hline Phenolic compounds (as phenol) & 0.2 \\
\hline Chlorine (free) & 1.0 \\
\hline Cadmium, $\mathrm{Cd}$ & $<1$ \\
\hline Chromium (trivalent and hexavalent) & $<1$ \\
\hline Copper & $<1$ \\
\hline Lead & $<1$ \\
\hline Mercury & 0.05 \\
\hline Nickel & $<1$ \\
\hline Selenium & $<1$ \\
\hline Silver & 0.1 \\
\hline Zinc & $<1$ \\
\hline Total metals & 3 \\
\hline Calcium (as $\left.\mathrm{Ca}^{2+}\right)$ & 200 \\
\hline Magnesium (as $\mathrm{Mg}^{2+}$ ) & 200 \\
\hline Boron (as B) & 5 \\
\hline Polychlorinated Biphenyl (PCBs) & 0.003 \\
\hline Pesticides (Total) & $<0.01$ \\
\hline Alpha emitters, $\mu \mathrm{c} / \mathrm{mL}$ & $10-7$ \\
\hline Beta emitters, $\mu \mathrm{c} / \mathrm{mL}$ & $10-6$ \\
\hline Coliform (daily average) & $500 \mathrm{MN} / 100 \mathrm{~mL}$ \\
\hline
\end{tabular}


The ineffectiveness of the effluent treatment plant of the Brewery industry could be attributed to the high acidity of their effluents, since effluents with low $\mathrm{pH}$ values can cause the impairment or malfunctioning of certain physico-chemical treatment processes [15].

The BOD values of the company exceeded the FEPA approved limit of $50 \mathrm{mgL}^{-1}$. High BOD values are hazardous for the survival of the aquatic biota in the receiving stream because oxygen is utilized by aquatic species to oxidize organic matter: $\mathrm{CH}_{2} \mathrm{O}+\mathrm{O}_{2}=\mathrm{CO}_{2}+$ $\mathrm{H}_{2} \mathrm{O}$ [7]. BOD represents the amount of oxygen utilized when the organic matter in a given volume of water is degraded biologically. It is a measure of the productivity of a particular water body. Any water body with has high BOD value, is starved of oxygen and needs more oxygen to completely degrade the organic life in it.

The value of Total dissolved oxygen (TDS) for the brewery industry is within the limit stated by FEPA (2000 ppm). TDS is a measure of the combined content of all organic and inorganic substances contained in water. However, TDS is not generally considered a primary pollutant (i.e., it is not deemed to be associated with health effects), it is used as an indication of aesthetic characteristics of drinking water and as an aggregate indicator of the presence of a broad array of chemical contaminants.
Chemical oxygen demand COD for the company was very high (more than two times the FEPA limit of $80 \mathrm{ppm}$ ). This showed that the effluents were seriously contaminated with organic pollutants, since COD is indirectly used to measure the amount of organic compounds in water.

Turbidity is a measure of the degree to which water loses its transparency due to the presence of suspended particulates; the more total suspended solids in water, the murkier it seems and the higher the turbidity. The turbidity of the effluents of the Brewery industry was 847 NTU. This figure is exceedingly high compared to the turbidity limit of 5 NTU for drinking water as stipulated by FEPA (though the limit for effluents was not stated). The suspended particles absorb heat from the sunlight, making turbid waters become warmer, and so reducing the concentration of oxygen in the water. The suspended particles also scatter the light, thereby decreasing the photosynthetic activities of aquatic plants and algae.

The hardness of the industrial effluent was 2000 ppm for the Brewery industry. This Figure was very high compared with the 200 ppm permissible limit for drinking water. Hard drinking water is generally not harmful to health, but can cause calcification of taps, boilers, kettles and other equipment used for handling water. Hard water is 
characterized by high mineral content; in domestic settings, hard water is often indicated by a lack of suds formation when soap is agitated in water.

The values of other physico-chemical parameters (nitrate, phosphate, chloride and sulphide) for the Brewery industry fell within the approved limit set by the FEPA, 1991. Phosphates and nitrates are required in small amounts for growth and metabolism of plants and animals. However, these minerals can be harmful in excess quantities as they can cause algae bloom and reduction in the amount of oxygen in water thereby causing the death of aquatic animals.

When sulphates exceed the recommended limit, it can have a negative impact on public health, potentially causing diarrhea which can be more of a problem in infants, the elderly and people with underlying health conditions. Chlorine on the other hand causes environmental problems and it is also harmful to living organisms in water and in the soil.

The accumulation of metals in an aquatic environment has direct consequences to man and to the ecosystem. Some metals like $\mathrm{Zn}$ and $\mathrm{Cu}$ are needed for metabolism in organisms. Interest in such metals lies in the thin line between their toxicity and essentiality. Some metals like $\mathrm{Al}, \mathrm{Cd}$ and $\mathrm{Pd}$ are extremely toxic even at trace levels.
From the results of the elemental analysis of the industrial effluent of the company, the values for $\mathrm{Cd}, \mathrm{Co}, \mathrm{Cr}, \mathrm{Fe}, \mathrm{Mg}, \mathrm{Ni}, \mathrm{Mn}$ and $\mathrm{Zn}$ fell within the range of the limit set by FEPA, 1991. The concentrations of Lead and Copper in the effluents of the Brewery industry were within the range of FEPA approved limit.

Lead in drinking water can cause a variety of adverse health effects. In babies and children, exposure to lead in drinking water above the action level can result in delays in physical and mental development, along with slight deficits in attention span and learning abilities. In adults, it can cause increase in blood pressure. Adults who drink this water over many years could develop kidney problems or high blood pressure.

Some people who drink water containing copper in excess may with short term exposure experience gastrointestinal distress, and with long term exposure may experience liver or kidney damage.

\section{Conclusion}

The study has shown that the Brewery Industry effluents had their BOD, COD, EC, Turbidity and Color above the required WHO/FEPA standards. This undoubtedly has negative impacts both on the environment and the living things including human beings. Since the result of analyses have shown that the Brewery Industry effluents are not well-treated, it has been 
recommended that Regulatory agencies of states and Nigeria should monitor and ensure compliance of proper effluent treatment by industries.

\section{References}

[1]. B. Adigun, Water quality management in aquaculture and freshwater zooplankton production for use in fish hatcheries, Alabi Printing Production, Nigeria, 2005, p 22.

[2]. S. Adhikari, S. Gupta, S.K. Banerjee, J. Ind. Soc. Soil Sci., 1993, 1, 170-172.

[3].P.S. Hooda, B.J. Alloway, Sci. Total Environ., 1993, 149, 39-51.

[4]. S.A. Ahmad, R. Rizvi, The Environ. Monitor J., 2003, 12 , 21-22.

[5]. K. Ahmed, Sci. Technol. Develop., 2000, 19, 12-17.

[6]. J. Ali, M.A. Javaid, J. Eng. Appl. Sci.,1997, 16, 43-47.

[7]. American Public Health Association (APHA), Standard Methods for Examination of Water and Waste water, American Public Health Association, Washington, 1998, p. 1130.

[8]. E.0. Anna, N.O. Adedipe, Water quality monitoring and environmental status in Nigeria, FEPA Monograph 6, FEPA, Abuja, 1996, p 239.

[9]. A. Ansar, F. Khad, The Botanical Review, 2005, 71, 449-82.

[10]. Y.A. Marvin, McGraw-Hill Encyclopedia of Science and Technology, McGraw-Hill Inc., New York, 1971, p 96-112. [11]. O.I. Muhibbu-din, A.O., Aduwo, A.A. Adedeji, Study of physico-chemical parameters of effluent impacted stream in Obafemi Awolowo, 2011.

[12]. N.H. Syed, A study of polluted ecosystem of industrial areas caused by the industrial effluents, Bahauddin Zakariya University, Multan, Pakistan, 2008, p 18-29. [13]. World Health Organization (WHO), Guidelines for drinking-water quality, Health Criteria and other supporting information, Geneva, 1990.

[14]. World Health Organization (WHO), Trace elements in human nutrition, Technical report series, Geneva, 1990.

[15]. World Health Organization (WHO), Health guidelines for use of wastewater in agriculture and aquaculture. Technical Report Series 778. Geneva, 1989, p 65-69.

\section{How to cite this manuscript: Iwuozor Kingsley Ogemdi*, Emuobosa Ejiroghene Gold, The} Physico-Chemical Parameters of Industrial Efflents from a Brewery Industry in Imo State, Nigeria, $A d v$. J. Chem. A, 2018, 1, 66-78. 